\title{
IMPLICATION OF GEOLOGICAL DOMAINS DATA FOR MODELING AND ESTIMATING RESOURCES FROM NKOUT IRON DEPOSIT (SOUTH-CAMEROUN)
}

\author{
A.W. Boroh ${ }^{1 \#, ~ K . Y . ~ S o r e-G a m o ', ~ M . ~ A y i w o u o ~ N g o u n o u n o ², ~}$ \\ I.B. Gbambie Mbowou', I. Ngounouno ${ }^{1}$ \\ 1 University of Ngaoundere, School of Geology and Mining Engineering, Meiganga, Cameroon \\ ${ }^{2}$ Ministry of Mines and Technological Industries, Yaoundé, Cameroun
}

Received: February 16, 2021; Accepted: July 29, 2021

\begin{abstract}
This paper is devoted to determining whether the addition of geological information can improve the resource estimate of mineral resources. The geochemical data used come from 116 drill holes in the Nkout East iron deposit in southern Cameroon. These geochemical data are modeled on Surpac and Isatis softwares to represent the 3D geochemical distribution of iron in the deposit. Statistical analysis and then a variographic study is performed to study the spatial variability of iron. Estimation domains were defined based on the results of geological and geochemical analyses. Four domains were determined. These domains are the saprolitic domain in particular; the poor domain or fresh rocks such as amphibolites, granites, and gneisses; the rich domain or oxidized rocks (BIF) and the metasediment domain. Block modeling of the deposit is performed to estimate the resource. The grade of each block was estimated by using ordinary kriging and composites from each domain. This study also consisted of comparing two types of estimate, notably the domain estimate and the global estimate. The cross-validation made it possible to authenticate the obtained models. From this comparison, the domain estimation brings more precision the global estimate precisely on the error analysis while if we take into account the point clouds of the predicted and estimated values, the estimation by geochemical modelling provides the best results.
\end{abstract}

Key words: Information effect; Support effect; Geological domain; Geochemical modelling.

\section{Introduction}

The estimation of recoverable resources, on a global or local scale, has become a standard geostatistical application in the mining industry [1]. At the start of the analysis of the recoverable resource problem in the 1970s, both the support effect and the information effect were identified as playing a potentially important role in the result [2]. To date, the support effect and the information effect are used significantly for writing estimate reports. Geostatisticians then resort to the notion of domain estimation [3]. On the one hand, the domains by geochemical grade are distinguished. The domain estimation involves the fragmentation of the deposit in intervals of regular or irregular grades for the estimation by making a correlation with the geology [4]. On the other hand, the geological domains of a deposit are identified as a considerable support in the estimation of resources and their identification is an important step in the definition of the estimation domains for the quantification of a deposit because of the heterogeneity of the deposit $[5,6]$. Indeed, estimation domains can subsequently be modeled and used as a basis for geostatistical analyzes [7, 8], given that in geostatistics, the support is the physical size characterized by geometry and the orientation of the volume on which the regionalized variable $Z$ is measured [9]. Glacken and Snowden have suggested that domain estimation is better than estimation without domain consideration [10], but this theory has been refuted by some studies which prove the opposite $[11,7]$.

In the estimation of mineral resources, the identification of geological domains to be used for definition, modeling and estimation of these domains is a major concern. Generally, only the information effect is taken into account, the support effect being often overlooked. The main objective of this paper is to judge the relevance of adding geological information to improve the estimate of deposits. More specifically, it is a question of identifying estimation domains from the

\#Corresponding author: williamboroh@gmail.com 
geological domains of the deposit, of estimating the tonnage, and of evaluating the quantity of metal of each domain in order to compare it with the global estimate without consideration of areas.

\section{Geological context of the study area}

The southern Cameroon area has given rise to a great deal of work and research, both geological and geomorphological [12-15]. The geological data of South Cameroon are extracted from documents and geological maps $[16,17]$ modified by Lerouge [18] at 1:200,000 (see Figure 1) available and published.
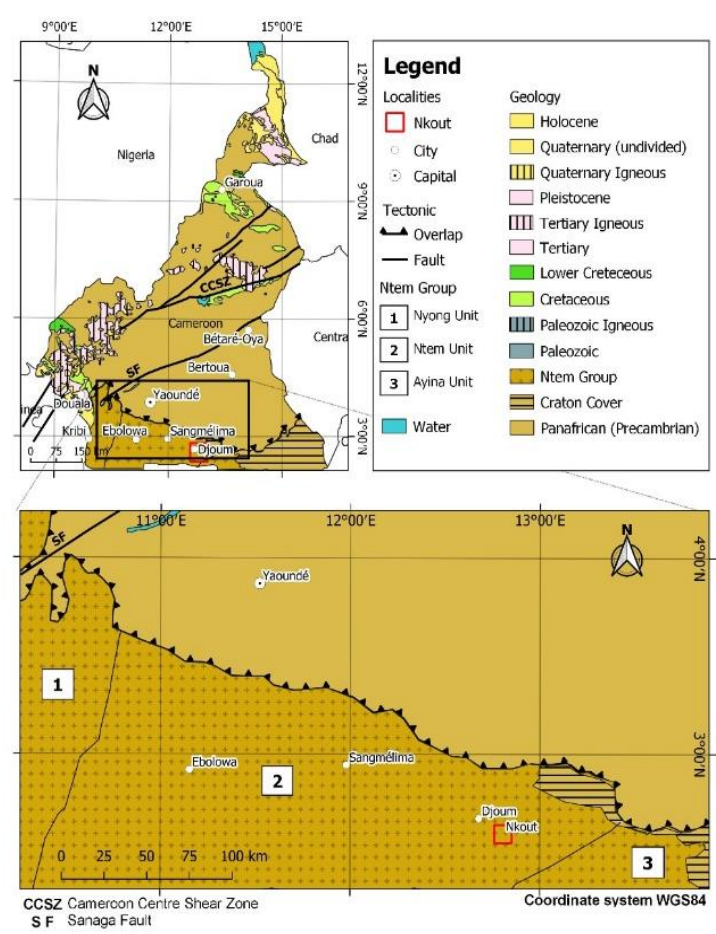

Figure 1 Local geology of Cameroon (modified from [19])

Our study area belongs to the lithostructural unit of lower Nyong which includes the greenstone belt (pyrograrnites, pyroxeno-amphibolites, peridotites, garnetites, talcschists, quartzites and itabirites), the laminated series (gneiss, garnetite and amphibolites), plutonites (granodiorites and syenites) and doleritic veins. Pyroxenites, talcschists and amphibolites are believed to come from Archean greenstone belts belonging to the Nyong unit, the main beam of which is formed by the Mamelles - Mewongo - Ngovayang Eséka alignment) $[18,19,16]$. The hydrothermal and meteoric aspect is respectively underlined by the presence of iron sulphides (pyrite, chalcopyrite, arsenopyrites) and chlorite. This NE-SWoriented unit rises to over $1000 \mathrm{~m}$ altitude and borders the Ntem group to the west. Geochronological studies give it a Paleoproterozoic age despite abundant relics, Archean and the signs of Neoproterozoic rejuvenation. A quick recognition of the study area from Figure 1 shows that it consists of orthopyroxene gneisses, hornblende-Biotite gneisses and Neoproterozoic formations of the Yaoundé group. Petrostructural and geomorphological analyzes show that this region has been affected by three phases of deformation, the most important of which (the second) has set up tectonic units in mega synforms and antiforms [20] The geological map of the study area is presented in Figure 1.

\section{Definition of geological estimation domains}

An in-depth phased approach has been developed. It is based on a combination of geological and geochemical analyses. This approach is more detailed and takes more time, but it provides a better support for the estimation because it is based on the decomposition of the problem by describing and modeling the geological layers and their geochemistry. The definition of the estimation domains begins with the geological knowledge of the area. It is therefore important to carry out a stratigraphic study first to observe the distribution of the lithological layers. These geological layers and their distributions are used as basic elements for the definition of the estimation domains. The next step is to study the variability of the iron content (\%) in the boreholes. This is based on the geochemistry, overall abundance in the deposit, and the information about the drill holes. A few litho-geochemical logs were thus modeled to better observe the distribution of iron content in the rocks and their arrangement in the area. Third, the estimation domains are based on all the reasonable combinations of geological attributes and their grades. In order to automatically define the domains, a Matlab code has been written (see Appendix B). These domains are:

- the saprolitic or lateritic domain (superficial layers). This domain is made up of laterites and surface layers. This zone is very rich in iron on the one hand (content up to $64 \%$ ), and parts with variable contents depending on the degree of weathering of the rocks;

- the poor domain (group of granitic intrusions, pegmatites, amphibolites, gneiss): this domain is made 
up of fresh rocks which are amphibolites, granites, pegmatites and gneisses. Most of these rocks have low iron content;

- the rich domain or domain of oxidized rocks (group of itabirites, BIF hematite and magnetite): BIF (hematites, magnetites) here contain high iron content;

- the domain of metasediments (group of metasediments, schists and quartzites): metasediments and metasedimentary rocks in this domain have a low iron content. These rocks have undergone extensive metamorphism. Table 1 presents a summary of the estimation domains defined.

Table 1 Lithology of estimation domains

\begin{tabular}{lll}
\hline Lithology & Estimation domains & Code \\
\hline $\begin{array}{l}\text { Laterites } \\
\text { Saprolites } \\
\text { Gneiss }\end{array}$ & $\begin{array}{l}\text { Saprolitic and lateritic } \\
\text { domain }\end{array}$ & D1 \\
$\begin{array}{l}\text { Granite } \\
\text { Pegmatite }\end{array}$ & Poor domain & D2 \\
$\begin{array}{l}\text { Magnetite BIF } \\
\text { Hematite BIF }\end{array}$ & Rich domain & D3 \\
$\begin{array}{l}\text { Itabirites } \\
\text { Metasediments } \\
\text { Quartzites and } \\
\text { veins }\end{array}$ & Metasediments domain & D4 \\
Schist & & \\
\hline
\end{tabular}

\section{Results and discussions}

\subsection{Geochemical and geological modelling}

The iron geochemical model of Nkout East is presented in Figure 2.

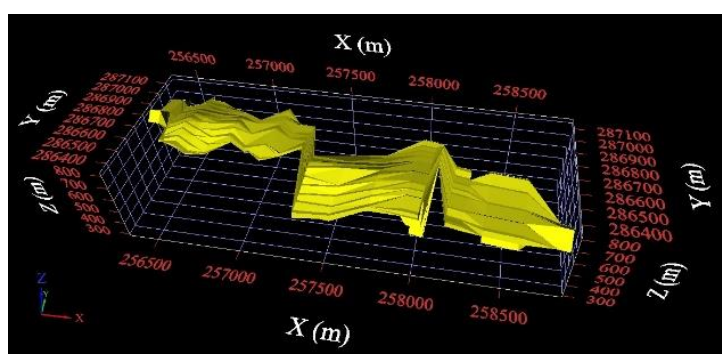

Figure 2 Iron geochemical model of Nkout East obtained by triangulation between iron ore sections

This model represents the $3 \mathrm{D}$ geochemical distribution of iron in the deposit. Indeed, the drawn geological forms should be based on a sufficient amount of borehole information and other geological knowledge which could include an ore deposit model, surface mapping, and structural and radiometric information. This type of model was created by the segment method while respecting the rules of modelling [21]. The geochemical data was modeled on Surpac before being exported to Isatis for studies. The model obtained represents the iron content of the deposit. The volume of the geochemical model is $62077119 \mathrm{~m}^{3}$, the surface is $3219760 \mathrm{~m}^{2}$.

Concerning the geological modeling of domains, the characteristics of this three-dimensional model of the fields of the deposit are established in Table 2 and Nkout East geological domain modeling is illustrated in Figure 3 .

Table 2 Surface and volume of the geological model 3D

\begin{tabular}{lccc} 
& D1 & D2 & D3 \\
\cline { 2 - 4 } $\begin{array}{l}\text { Surface in } \\
\mathrm{m}^{2}\end{array}$ & 2671442 & 2527721 & 2651771 \\
$\begin{array}{l}\text { Volume in } \\
\mathrm{m}^{3}\end{array}$ & 14921078 & 39037962 & 50231970 \\
\hline $\begin{array}{l}\text { Surface in } \\
\mathrm{m}^{2}\end{array}$ & 2651771 & 2458828 & 10309762 \\
\cline { 2 - 4 } $\begin{array}{l}\text { Volume in } \\
\mathrm{m}^{3}\end{array}$ & 50231970 & 41593959 & 145784969 \\
\hline
\end{tabular}

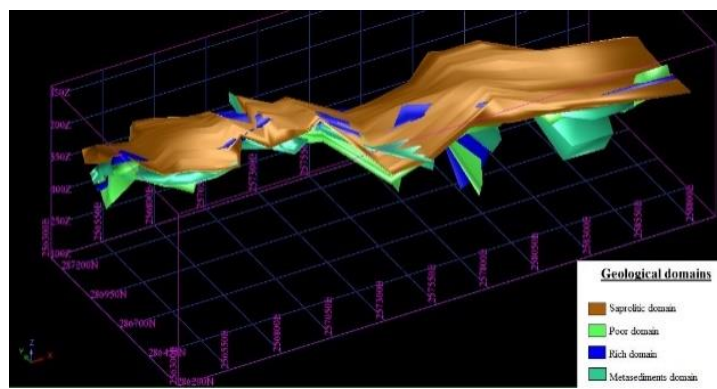

Figure 3 Nkout East geological domain modeling smoothed

A 3D geological model of the Nkout East deposit was built on the basis of drilling data and fields defined previously. Each model is representative of the rocks constituting the domain. Smoothing (see Figure 3) was then applied to the model to eliminate the rough surfaces associated with triangulation. The colorations observed on the model refer to the different fields. The saprolitic domain is found more on the surface. 


\subsection{Exploratory data analysis}

The histogram of the iron composites of Nkout East over the entire deposit is given in Figure 4.

In Figure 4, it appears that this histogram follows a normal law with an average of $27.18 \%$ and a standard deviation of $19.86 \%$. The coefficient of variation is 0.7237. The maximum value is $67.17 \%$ and the minimum value $0.48 \%$. The histogram is unimodal and the lowest levels (0 to 10\%) have the highest frequencies. Table 3 and Figure 5 give the statistical parameters and the histograms of the different geological domains modeled at Nkout East.

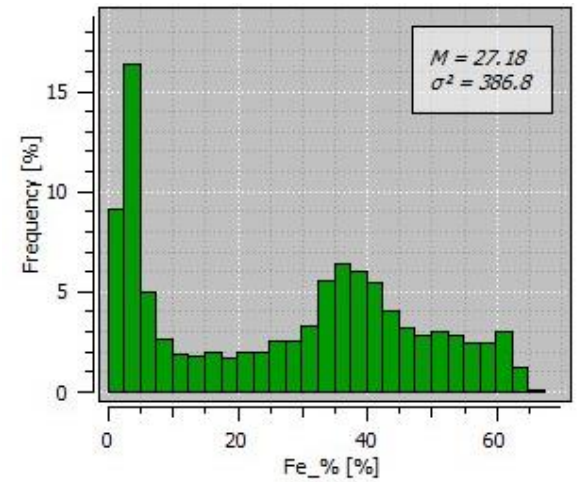

Figure 4 Histogram of iron grade of Nkout East
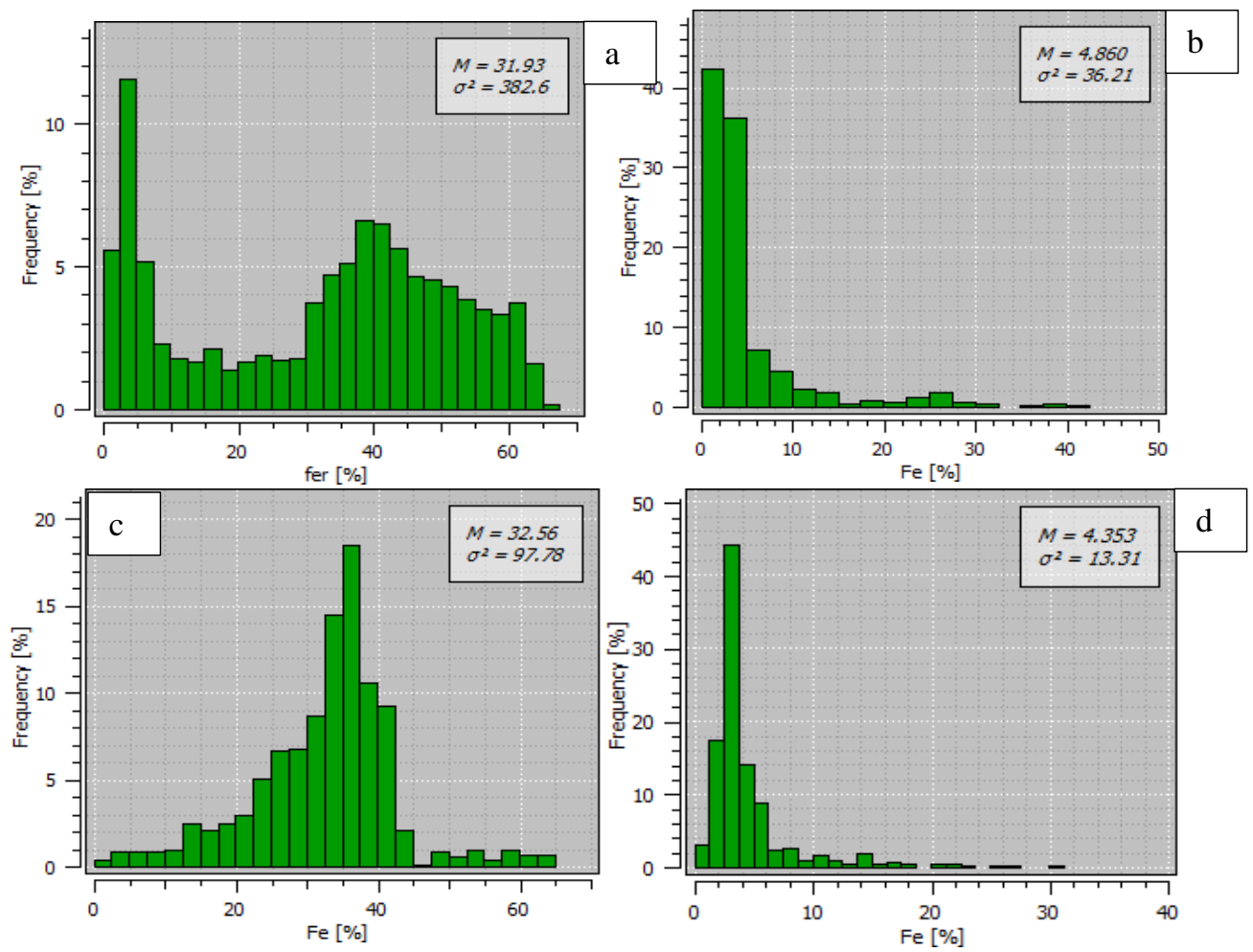

Figure 5 Histograms of iron grades by domains: a) D1; b) D2; c) D3 and d) D4

Table 3 Statistical parameters of iron grade

\begin{tabular}{lcccccc}
\hline Domains & Count & Minimum & Maximum & Mean & Standard deviation & Variation coefficient $(\sigma / \mathrm{m})$ \\
\hline Global & 4816 & 0.48 & 67.17 & 27.18 & 19.67 & 0.7237 \\
D1 & 4657 & 0.48 & 67.17 & 31.93 & 19.56 & 0.6126 \\
D2 & 1508 & 0.59 & 40.18 & 4.860 & 6.018 & 1.238272 \\
D3 & 1178 & 0.62 & 64.11 & 32.56 & 9.888 & 0.30369 \\
D4 & 646 & 0.61 & 30.83 & 4.353 & 3.648 & 0.838043 \\
\hline
\end{tabular}


Domain D1 has characteristics close to the total geochemical domain, in particular concerning the minimum and maximum and also the normal shape of its histogram. It is also the area with the lowest $(0.67 \%)$ and highest (67.17\%) grade.

Domain D2 and domain D4 present lognormal histograms (see Figures $5 b$ and $5 d$ ) with the lowest contents and variances but also a large part of the data considered to be outliers [22]. These areas are considered uninteresting from a grade point of view.

Domain D3, judged to be the rich domain, has the best characteristics, in particular the largest average at $32.56 \%$ and the smallest correlation coefficient equal to 0.3 sign of the small dispersion of iron in the domain.

\subsection{Structural Analysis}

Structural analysis is performed to find the spatial correlation of the studied item [23-24]. A variogram map is a plot of experimental variogram values in a coordinate system (hx, hy) with the center of the map corresponding to the variogram at a shift of $(0,0)[25]$. Its use makes it possible to determine the major directions of the mineralization and then to construct variograms according to these directions. The primary variogram map of the total geochemical domain is shown in Figure 6.

In Figure 6, a major direction $\mathrm{N}^{\circ}$ of dip $70^{\circ}$ is shown. The $3 \mathrm{D}$ variogram extracted from this map as well as from the other secondary and tertiary variogram maps is given in Figure 7. This 3D variogram of geochemical domain is illustrated in Figure 7.

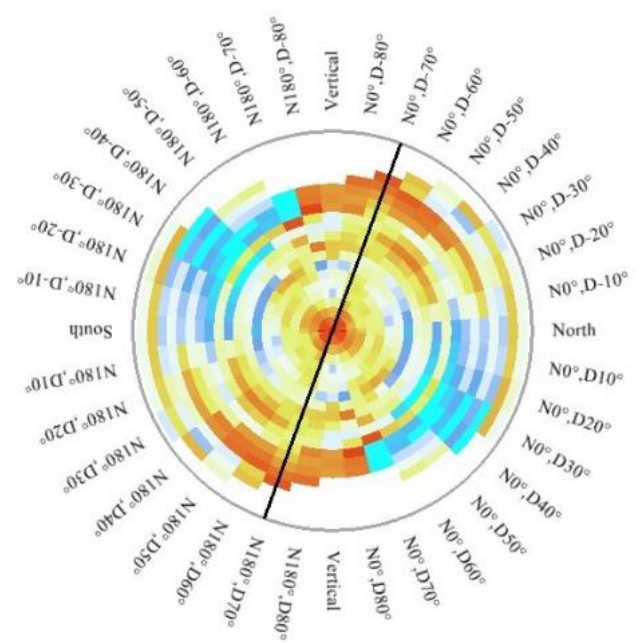

Figure 6 Variogram map of geochemical domain

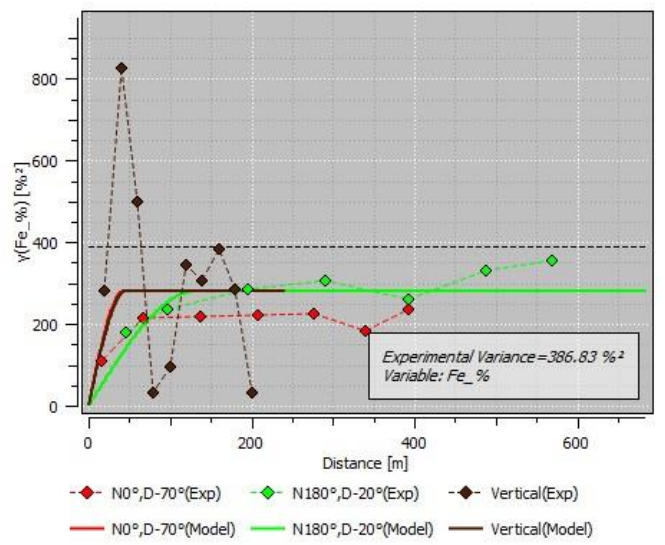

Figure 7 3D variogram of geochemical domains 
These variograms were calculated with a step of $100 \mathrm{~m}$ and $10^{\circ}$, angular tolerance except for the vertical variogram which uses a step of $20 \mathrm{~m}$ with $5^{\circ}$ angular tolerance, because of the small thickness of the geochemical model. The three variograms have a spherical model. The pattern nugget effect is $0 \%^{2}$ and the spherical component $\mathrm{C}$ is $280.90 \%^{2}$. The lags are $132.1 \mathrm{~m}, 43.25 \mathrm{~m}$, and $43.25 \mathrm{~m}$ respectively. The

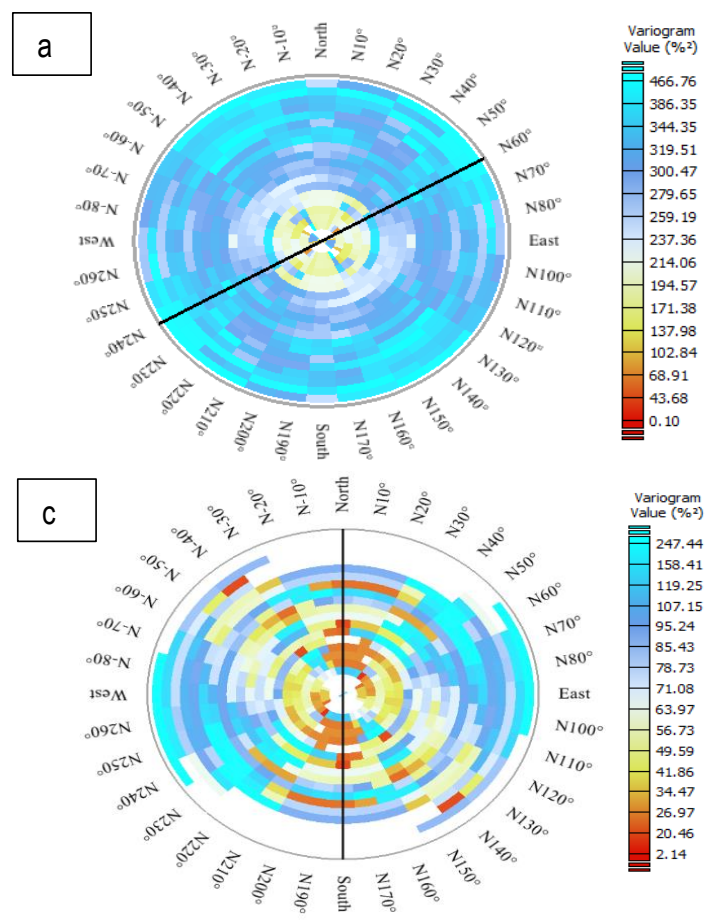

variogram maps of structural analysis of geological domains are presented in Figure 8.

Figure 8 shows the structural analysis by geological domains. In domain $\mathrm{D} 1$, the variogram values vary from 0.10 to $466.76 \%{ }^{2}$. The primary variogram map obtained is quasi-isotropic because it does not note any major variation in the value of variograms. However, the major direction chosen is $\mathrm{N}^{\circ} \mathrm{E}^{\circ}$.

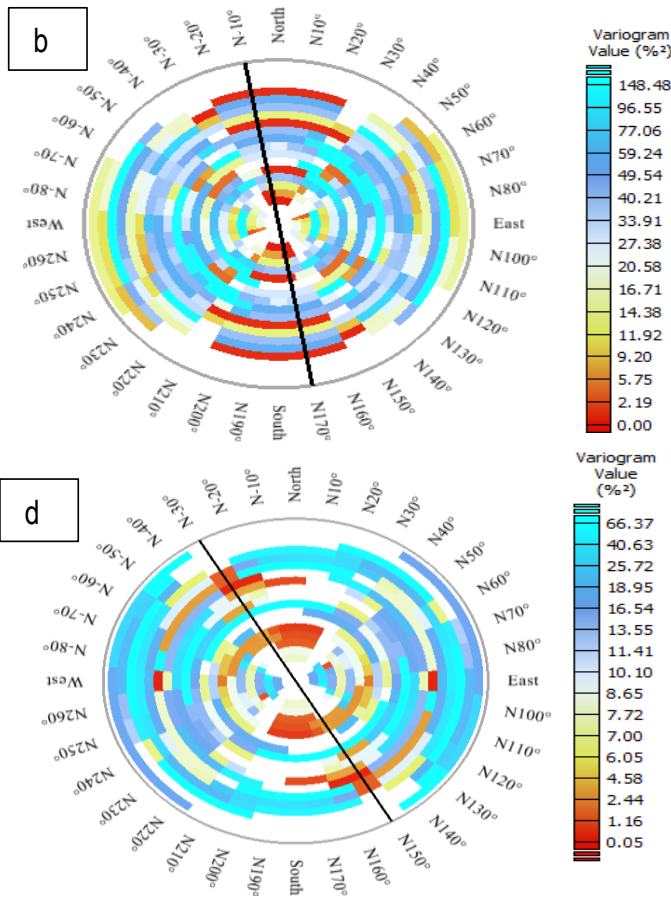

Figure 8 Variogram maps of geological domains: a) D1; b) D2; c) D3 and d) D4

The variogram map of domain D2 shows a variation between 0 and $148.48 \%^{2}$. The major direction in the plane is $\mathrm{N} 170^{\circ}$, large discontinuities in this area are observed. Thus, two variograms will be modeled, following the major direction of continuity $\mathrm{N}-19.9^{\circ}$ dip $1.7^{\circ}$ and following the direction $\mathrm{N} 249.8^{\circ}$ dip $-9.8^{\circ}$ that represents the secondary direction of continuity. The variogram following the direction could not be calculated.

The rich domain (D3) clearly shows a preferential direction following the major direction of continuity $\mathrm{N}$ $159.6^{\circ}$ dip $-22^{\circ}$ and minor following the direction $\mathrm{N}$ $228.1^{\circ}$ dip $41.6^{\circ}$. It also has the largest calculated theoretical variogram value.

Finally, the values of the variogram map of domain
D4 vary from 0 to $66.37 \%^{2}$ (See Figure $8 d$ ). The major direction of continuity in the plane is $\mathrm{N} 150^{\circ} \mathrm{E}$. Thus, three variograms will be modeled, following the major direction of continuity $\mathrm{N} 150 \mathrm{E}^{\circ}\left(\mathrm{N}-30^{\circ}\right)$ and following the secondary direction $\mathrm{N} 240^{\circ} \mathrm{E}$ dip - $20^{\circ}$ that represents the secondary direction of continuity and the vertical direction. The 3D variograms of geological domains are shown in Figure 9.

The variogram of domain D4 (see Figure 9d) is the only one that has a vertical component, because of the low thickness of the layers of the other domains. Figure 9a shows an omnidirectional variogram for domain D1. This choice was made because of the isotropy of its variogram map (see Figure 8). The Table 4 provides the characteristics of the variogram models. 

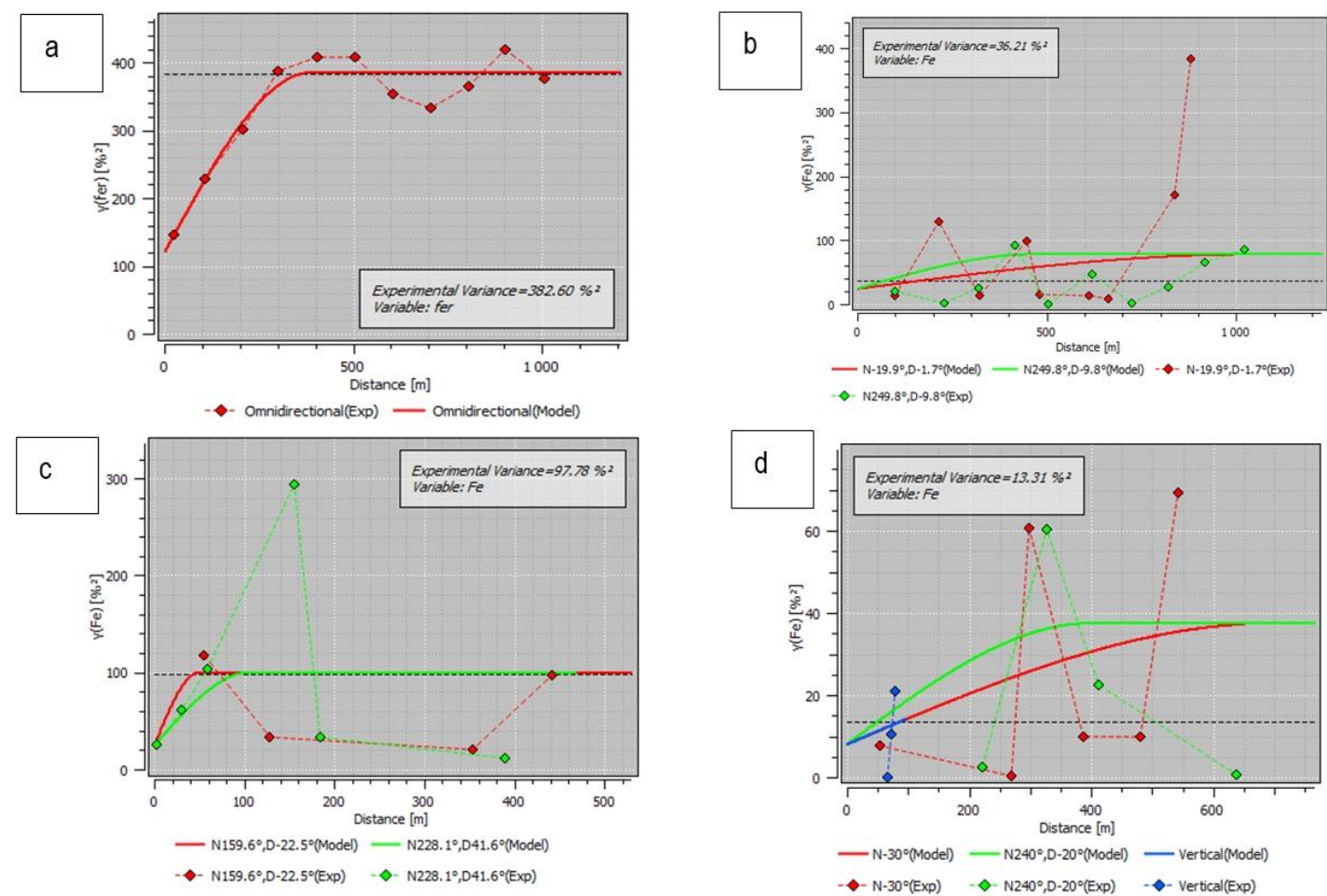

Figure 9 3D variograms of geological domains: a) D1; b) D2; c) D3 and d) D4

Table 4 Characteristics of variogram models for estimation

\begin{tabular}{lllccc}
\hline Domain & Direction & Model & Nugget $\left(\%^{2}\right)$ & Range $(\mathrm{m})$ & Sill $\left(\%^{2}\right)$ \\
\hline D1 & omnidirectionnal & Spherical & 119.18 & $389.5 \mathrm{~m}$ & 266.27 \\
D2 & $\mathrm{N}-19.9^{\circ}\left(-1.7^{\circ}\right)$ & Spherical & 23.90 & 301.9 & 80 \\
& $\mathrm{~N} 249.8^{\circ}\left(-9.8^{\circ}\right)$ & Spherical & 23.90 & 1393 & 80 \\
D3 & $\mathrm{N} 159.6^{\circ}\left(-22.5^{\circ}\right)$ & Spherical & 24.23 & 44.48 & 101.16 \\
& $\mathrm{~N} 228.1^{\circ}\left(41.6^{\circ}\right)$ & Spherical & 24.23 & 106.9 & 101.16 \\
& $\mathrm{~N} 150^{\circ}$ & Spherical & 8 & 700 & 38.51 \\
D4 & $\mathrm{N} 240^{\circ}\left(-20^{\circ}\right)$ & Spherical & 8 & 400 & 38.51 \\
& Vertical & Spherical & 8 & & \\
\hline
\end{tabular}

\subsection{Resource estimation}

It is an operation which consists of determining the volume and tonnage values of the model blocks relating to each zone. The volume of the blocks is easily calculated knowing their dimensions. Figures 10 and 11 illustrate the density analyzes carried out first on the entire Nkout East deposit then on each subdivided domain.

The resource estimate takes into account the value of the density of the layers present in the area to be estimated. In the absence of a density compositing, it is important to find a density value corresponding to all the layers; this is done by a correlation via linear regression between the measured density values and the contents [23]. The equations obtained for the calculation of the density as a function of iron are linear in the form $y=a x$ $+b$ where $y$ is the density and $x$ is iron. In all cases, the coefficient $a$ is close to zero, which means that the iron has minimal impact on the density value; therefore, the value of $b$ will be used. Table 5 presents the separation into domains which allows us to appreciate the density values which correspond to the lithologies crossed. 
The highest density is that of the BIF domain and the lowest is the density of metasediments. The loss of information was made during the overall estimation because the density obtained in this case is only close to that of domain $\mathrm{D} 1$

To facilitate resource estimation, block modeling of the deposit is performed. Different block sizes were chosen for each domain, these choices depend on the geometry of the geological / geochemical model, on the method of exploiting the spacing between the boreholes, and on the compositing [26]. Using ordinary kriging and composites from each domain, the grade of each block was estimated. One of the most common approaches to obtaining the block estimate is to discretize a block at many points which are estimated using the point kriging approach. Then, the block grade can be obtained by averaging all of the individual point estimates in the block. This robust approach gives good results and is used in most specialized computer programs for mining geology applications [27].

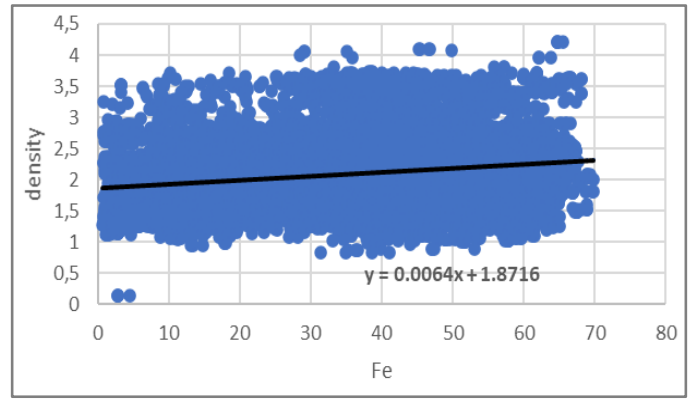

Figure 10 Density analysis of global domain
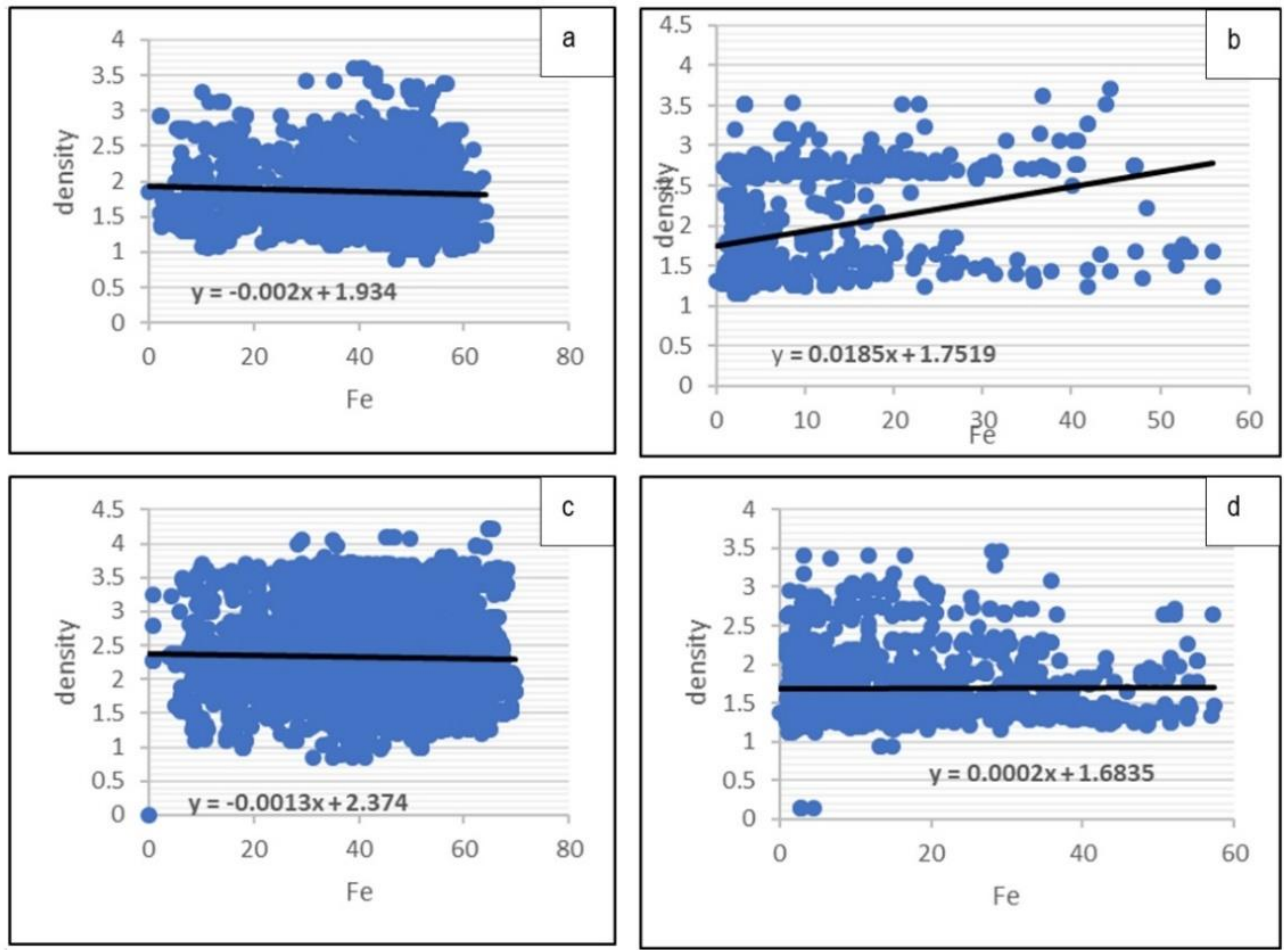

Figure 11 Density analysis for geological domains: a) D1; b) D2; c) D3 and d) D4

Table 5 Density of domains

\begin{tabular}{ll}
\hline Domain & Density \\
\hline Geochemical & 1.87 \\
D1 & 1.93 \\
D2 & 1.75 \\
D3 & 2.37 \\
D4 & 1.68 \\
\hline
\end{tabular}

The estimates were made with a minimum of 5 points and a maximum of 15 points. Figure 12 shows the block model of the total geochemical domain.

The number of sample blocks selected is 5570 units, or $25.87 \%$ of the model block. The contents vary between 0.38 and $64.41 \%$. The average grade of the blocks is $22.66 \%$. The standard deviation of kriging is 
$15.90 \%$. With 3013 points used, the neighborhood search ellipsoid has the following characteristics:

- The radius of $272.42 \mathrm{~m}$ in $\mathrm{X}, 261.49 \mathrm{~m}$ in $\mathrm{Y}$ and 21.29

$m$ in $Z$;

- Rotation of $-5^{\circ}$ along $Z$.

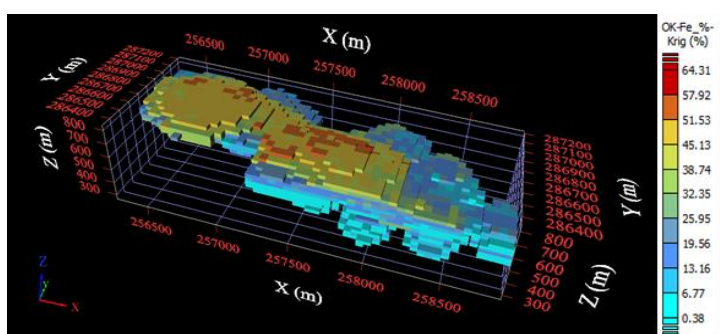

Figure 12 Block model of geochemical domain

The block used to model domain 1 has 6016 subblocks. The estimated geochemical model is shown in Figure 13.

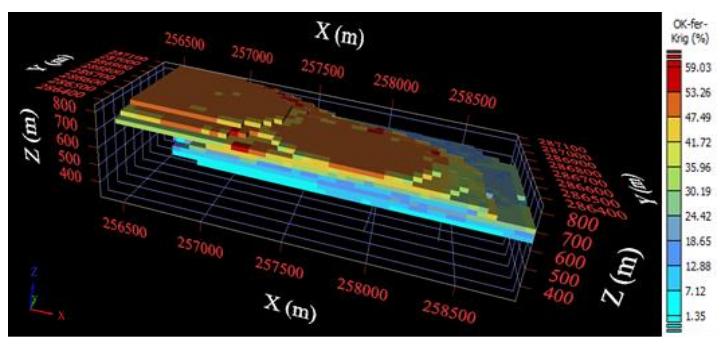

Figure 13 Block model of domain D1

Figure 13 contains 4383 sample blocks that represent $72.86 \%$ of blocks. The iron content varies between $1.35 \%$ and $59.03 \%$. The average content is $29.55 \%$ and the standard deviation is $14.65 \%$. The richest blocks are located on the surface. About 4888 composite data were used; the neighborhood search ellipsoid has the following characteristics:

- The radius of $1045.46 \mathrm{~m}$ in $\mathrm{X}, 467.78 \mathrm{~m}$ in $\mathrm{Y}$ and 44.11 $m$ in Z;

- Rotation of $-5^{\circ}$ along $\mathrm{Z}$.

The block model of domain D2 is shown in Figure 14. In Figure 14 domain D2 consists of 9758 sample blocks, after estimation, 544 sub-blocks have been preserved, i.e., $5.57 \%$. The iron content varies between $1.61 \%$ and $31.84 \%$. The average content is $7.03 \%$ and the standard deviation $4.50 \%$. With 4089 points used, the neighborhood search ellipsoid has the following characteristics:

- The radius of $450 \mathrm{~m}$ in $\mathrm{X}, 250 \mathrm{~m}$ in $\mathrm{Y}$ and $100 \mathrm{~m}$ in $\mathrm{Z}$; - Rotation of $-5^{\circ}$ along $Z$.

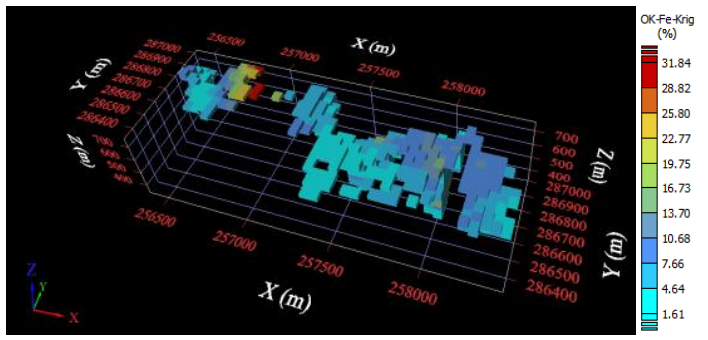

Figure 14 Block model of domain D2

The block used to model domain 3 is illustrated in Figure 15.

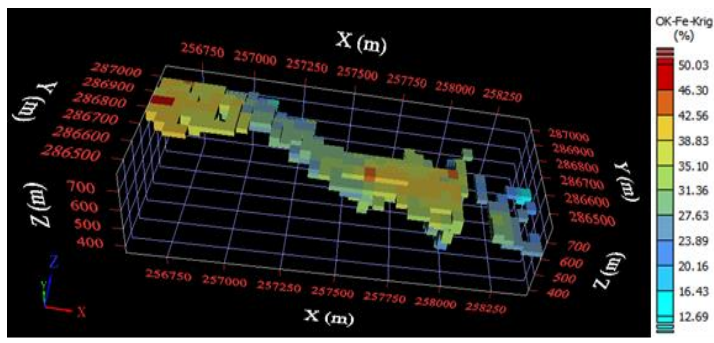

Figure 15 Block model of domain D3

In Figure 15, the block model consists of 8177 sample blocks, after estimation, 724 sub-blocks have been retained, i.e. $8.85 \%$ (see Figure 15). The iron content ranges from $12.69 \%$ to $50.03 \%$. The average content is $30.45 \%$ and the standard deviation $5.62 \%$. With 3634 points used, the neighborhood search ellipsoid has the following characteristics:

- The radius of $1014.18 \mathrm{~m}$ in $\mathrm{X}, 581.12 \mathrm{~m}$ in $\mathrm{Y}$ and 31.67 $m$ in Z;

- Rotation of $-5^{\circ}$ along $Z$.

The block model D4 is shown in Figure 16.

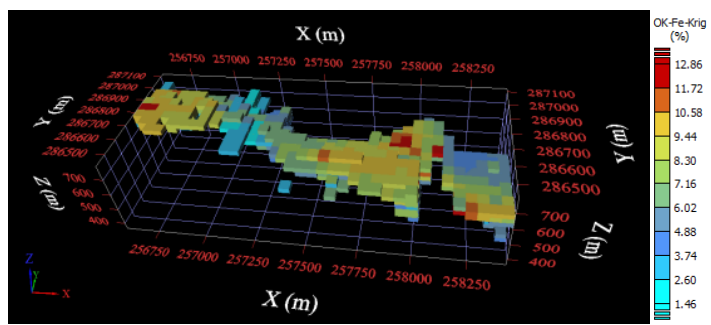

Figure 16 Block model of domain D4

The model block of domain 4 has 7252 sample blocks, after estimation, 351 sub-blocks have been preserved, or $4.84 \%$. The iron content ranges from $1.46 \%$ to $12.86 \%$. The average content is $5.82 \%$ and the standard deviation is $2.75 \%$. 


\subsection{Model authenticate: cross validation}

Determining the quality of a model involves its validation. One of the most used techniques is crossvalidation [28-30]. It is a process where certain samples are used to design the model, then are certain values of the output variable re-estimated; this method involves the use of statistical parameters in order to diagnose the reliability as well as its associated parameters [31].

This reliability test was performed using Isatis software. It was a question of analyzing the global model first, then the models of domain estimation. This is a comparison graph between the true values and the estimated values. The more the points are concentrated on the bisector, the better the correlation. Figure 17 shows the cross-validation correlogram of the global model.
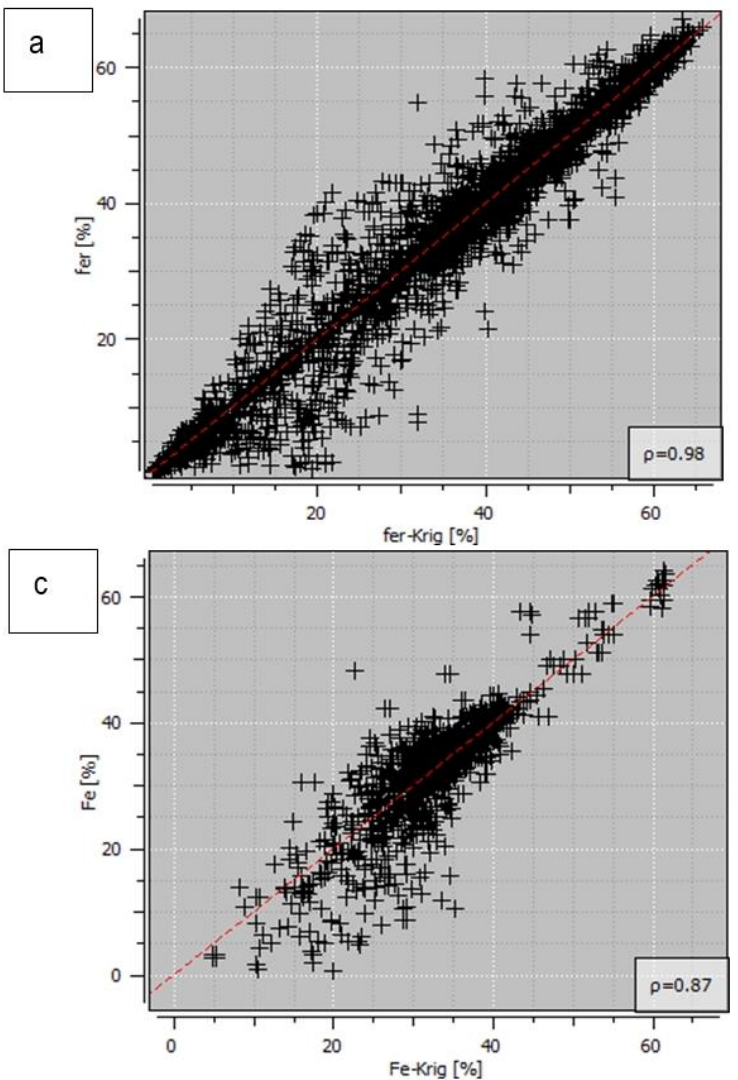

Figure 18 Cross-validation correlogram: a) D1; b) D2; c) D3 and d) D4

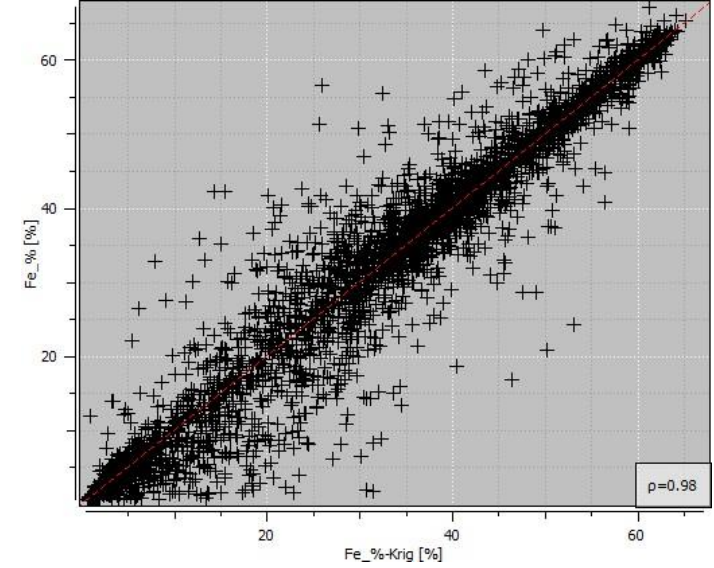

Figure 17 Cross-validation correlogram (global estimation)
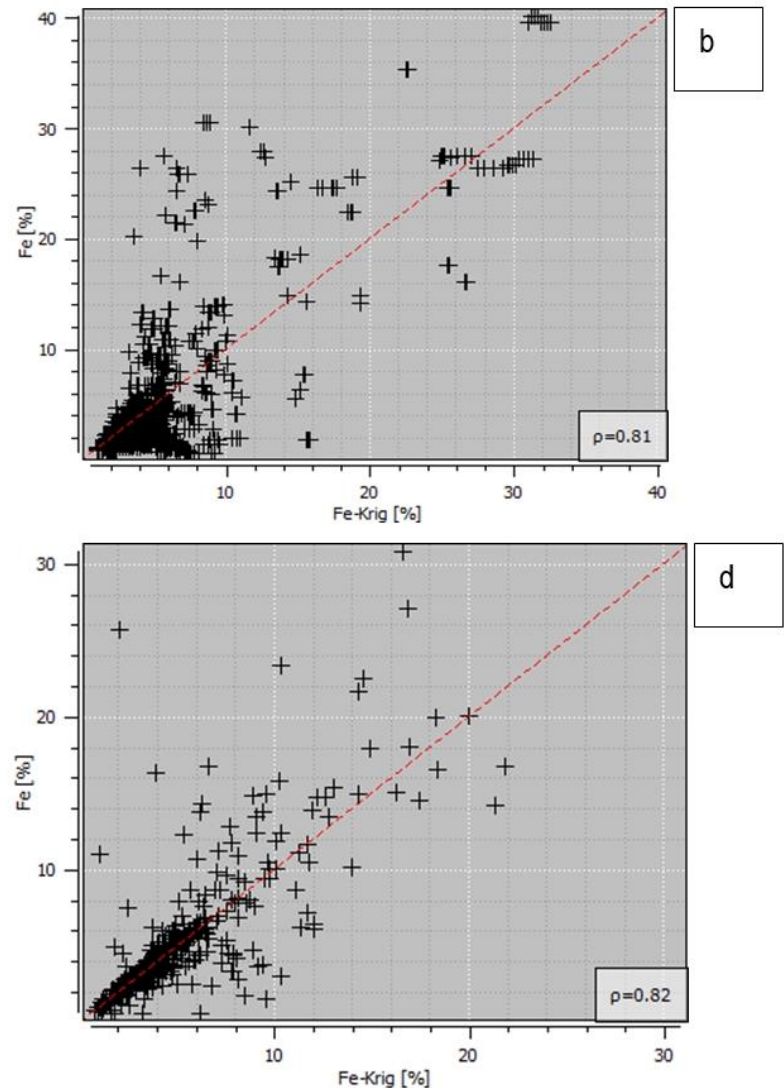

coefficient equal to 0.98 . The average of the errors is 0.02 . The confidence level is $99 \%$. The distribution is made along the bisector, therefore on all the data. For concentrated along the first bisector, which indicates good precision of the estimates with a high correlation 
the analysis by geological estimation domains, the correlograms were constructed and presented in Figure 18.
The results of the cross-validation comparison for all models are shown in Table 6.

Table 6 Comparison of the cross-validation parameters of the domain models and the global model

\begin{tabular}{lrcccc}
\hline & Global & Domain & 1 Domain 2 & Domain 3 & Domain 4 \\
\hline Mean error & 0.05 & 0.02 & -0.03 & 0.03 & -0.03 \\
Variance error & 17.36 & 12.18 & 12.55 & 12.045 & 7.898 \\
Variance of standardized errors & 1.48 & 0.8358 & 0.8053 & 0.8043 & 0.8639 \\
Mean of the variances of the standardized errors & 0.01 & 0 & -0.01 & 0 & -0.01 \\
\hline
\end{tabular}

The variance of the standardized errors of the domains is closer to 1 than that of the overall model, so the estimate using the domains is more precise than the overall estimate. In addition, the variance of the estimation errors of the global model is higher $(17.36 \%)$ than the domains $(12.18 \% ; 12.55 \% ; 12.045 \%$, and $7.898 \%$, respectively); this proves that the models by domains are more robust than the global model, hence a better estimate.

For domain 1 , the correlation cloud is very tight (Figure 18a), which reflects a good correlation between the estimated data and the real data with a high coefficient equal to 0.98 . The average of the errors is 0.02 . The confidence level is $99 \%$. The distribution is made all along the bisector because the contents of the domain are distributed from 0 to more than $60 \%$ iron. This domain, made up of saprolites and laterites, is rich in iron but also has zones that have been altered, hence the variability of the grade.

For domain 2, the data are concentrated along the bisector towards the extreme left at the bottom (Figure 18b). The correlation coefficient is 0.81 . The mean of the errors is -0.03 . This concentration shows us that this area is low content (average less than $10 \%$ ). The rocks constituting this domain are fresh rocks such as gneisses, amphibolites, granites, and pegmatites.

For domain 3, the data are grouped along the bisector in the center (Figure 18c). The correlation coefficient is 0.87 . The average of the errors is 0.03 . This concentration in the center shows us that this area is rich (average greater than $30 \%$ ), it is made up of oxidized rocks which are BIF (hematite and magnetite). Smaller values are greater than $10 \%$.

For domain 4, the data are grouped along the bisector towards the extreme left at the bottom (figure 18d). The correlation coefficient is 0.82 . The average of the errors is -0.02 : this concentration shows that this area is very low in iron (average less than $6 \%$ ). The maximum values do not exceed $22 \%$.

\section{Conclusion}

This paper was devoted to estimating the mineral deposit of East Nkout (South Cameroon) by geological domain with that made by geochemical modeling, and to compare two types of estimate. Statistical analysis and then a variographic study were performed to study the spatial variability of iron. The estimation models were then authenticated by cross-validation. On the one hand, the method by geochemical modeling gave a correlation coefficient of $98 \%$ while the modeling by geological domains provided as coefficient $98 \%, 81 \%$, $87 \%$, and $82 \%$ for the domains D1, D2, D3, and D4, respectively. On the other hand, by studying estimation errors, it turns out that the second method studied provided better results. From the two techniques, it is very difficult to make a choice which methodology to use for resource estimation; this may reflect a type of genetic deposit where the spatial distribution is simplistic. This is a characteristic of many sedimentary deposits that exhibit an absence of tectonic disturbance where difference between geochemical and geological domain modeling is therefore insignificant.

\section{Acknowledgments}

Our thanks go to the company Geovariances and more particularly Marie-Cécile FEBVEY for the Isatis.neo license which was used for the work of this article.

\section{References}

[1] Matheron, G. (1971) The theory of regionalised variables and its applications. Les Cahiers du Centre de Morphologie Mathématique, 5, 212.

[2] Deraisme, J., Roth, C. (2000) The information effect and estimating recoverable reserves. Proceedings geostatistics. 
[3] Rossi, M.E., Deutsch, C.V. (2014) Recoverable Resources: Estimation, in: Mineral Resource Estimation. Springer, pp. 133-150.

[4] Emery, X., Ortiz, J. (2005) Estimation of mineral resources using grade domains: critical analysis and a suggested methodology. J. South. Afr. Inst. Min. Metall. 105, 247-255.

[5] Ortiz, X., others, (2006) Geostatistical estimation of mineral resources with soft geological boundaries: a comparative study. J. South. Afr. Inst. Min. Metall. 106, 577-584.

[6] Kasmaee, S., Raspa, G., de Fouquet, C., Tinti, F., Bonduà, S., Bruno, R. (2019) Geostatistical Estimation of Multi-Domain Deposits with Transitional Boundaries: A Sensitivity Study for the Sechahun Iron Mine. Minerals 9, 115.

[7] Emery, X., others, (2007) Probabilistic modelling of lithological domains and it application to resource evaluation. J. South. Afr. Inst. Min. Metall. 107, 803-809.

[8] Wilde, B.J., Deutsch, C.V. (2012) Kriging and Simulation in Presence of Stationary Domains: Developments in Boundary Modeling, in: Abrahamsen, P., Hauge, R., Kolbjørnsen, O. (Eds.), Geostatistics Oslo 2012. Springer Netherlands, Dordrecht, pp. 289-300.

[9] Hocine, M., Balakrishnan, N., Colton, T., Everitt, B., Piegorsch, W., Ruggeri, F., Teugels, J. (2014) Wiley statsref: Statistics reference online. John Wiley \& Sons, Ltd.

[10] Glacken, I., Snowden, D. (2001) Mineral Resource Estimation By.

[11] Saito, H., McKenna, S.A., Zimmerman, D.A., Coburn, T.C. (2005) Geostatistical interpolation of object counts collected from multiple strip transects: Ordinary kriging versus finite domain kriging. Stoch. Environ. Res. Risk Assess. 19, 71-85.

[12] Gazel, J., Guiraudie, C., de Ribes, G.C., Hourcq, V., Nickles, M., Geologie, C.D. des M. et de la, (1956) Carte géologique du Cameroun. Direction des Mines et de la Geologie du Cameroun.

[13] Haugou, P., Koretzky, N. (1943) Carte géologique du Cameroun n 3 à 1/500.000 avec notice explicative. Serv Mines Cameroun Yaoundé.

[14] Korableff, G. (1940) Contribution à l'étude de la géologie et de la géologie appliquée de l'OubanguiChari oriental et du Cameroun sous mandat français. Libr. sociale et économique.

[15] Nicklès, M. (1952) Mollusques du Quaternaire marin de Port-Gentil (Gabon). Bull. Dir. Mines Géologie L'AEF 5, 75-101.

[16] Maurizot, P. (2000) Carte géologique du sud-ouest Cameroun. Échelle 1/50 000.

[17] Maurizot, P., Abessolo, A., Feybesse, J., Johan, V., Lecomte, P. (1986) Etude et prospection minière du Sud-Ouest Cameroun. Synthèse des travaux de 1978 à 1985. Rapp. BRGM 85 CMR 66, 274p.

[18] Lerouge, C., Cocherie, A., Toteu, S.F., Penaye, J., Milési, J.-P., Tchameni, R., Nsifa, E.N., Fanning, C.M., Deloule, E. (2006) Shrimp U-Pb zircon age evidence for Paleoproterozoic sedimentation and $2.05 \mathrm{Ga}$ syntectonic plutonism in the Nyong Group, South-Western Cameroon: consequences for the Eburnean-Transamazonian belt of NE Brazil and Central Africa. J. Afr. Earth Sci. 44, 413-427.

[19] Vicat, J.-P., Pouclet, A., Nsifa, E. (1998) Les Dolérites du Groupe du Ntem (Sud Cameroun) et des Régions Voisines (Centrafrique, Gabon, Congo, Bas Zaïre): Caractéristiques Géochimiques et Place dans L'évolution du Craton du Congo au Protérozoïque. Géologie Environ. Au Cameroun Collect. GEOCAM 305-324.

[20] Gweth, P.N., Dupuy, J., Matip, O., Fombutu, A., Kalngui, E. (2001) Mineral resources of Cameroon. SOPECAM Yaoundé 375.

[21] Ostensen, O.M., Smits, P.C. (2002) ISO/TC211: Standardisation of geographic information and geoinformatics. In IEEE International Geoscience and Remote Sensing Symposium Vol. 1, pp. 261263.

[22] Surpac, G., 2013. 6.6. 1.(2013). GEOVIA Surpac Ref. Man.

[23] Antinao, J.L., Gosse, J. (2009) Large rockslides in the Southern Central Andes of Chile (32-34.5 S): Tectonic control and significance for Quaternary landscape evolution. Geomorphology 104, 117-133.

[24] Chiles, J.-P., Delfiner, P. (2009) Geostatistics: modeling spatial uncertainty. John Wiley \& Sons.

[25] Gringarten, E., Deutsch, C., others, (1999) Methodology for variogram interpretation and modeling for improved reservoir characterization, in: Spe Annual Technical Conference and Exhibition. Society of Petroleum Engineers.

[26] Tercan, A.E., Ünver, B., Hindistan, M.A., Ertunç, G., Atalay, F., Ünal, S., Kıllıoğlu, Y. (2013) Seam modeling and resource estimation in the coalfields of western Anatolia. Int. J. Coal Geol. 112, 94-106.

[27] Abzalov, M. (2016) Applied mining geology. 
Springer.

[28] Browne, M.W. (2000) Cross-validation methods. J. Math. Psychol. 44, 108-132.

[29] Westerhuis, J.A., Hoefsloot, H.C., Smit, S., Vis, D.J., Smilde, A.K., van Velzen, E.J., van Duijnhoven, J.P., van Dorsten, F.A. (2008) Assessment of PLSDA cross validation. Metabolomics 4, 81-89.
[30] Arlot, S., Celisse, A., others, (2010) A survey of cross-validation procedures for model selection. Stat. Surv. 4, 40-79.

[31] Marko, K., Al-Amri, N.S., Elfeki, A.M. (2014) Geostatistical analysis using GIS for mapping groundwater quality: case study in the recharge area of Wadi Usfan, western Saudi Arabia. Arab. J. Geosci. 7, 5239-5252. 


\section{Appendices}

Appendix A Litho-geochemical logs

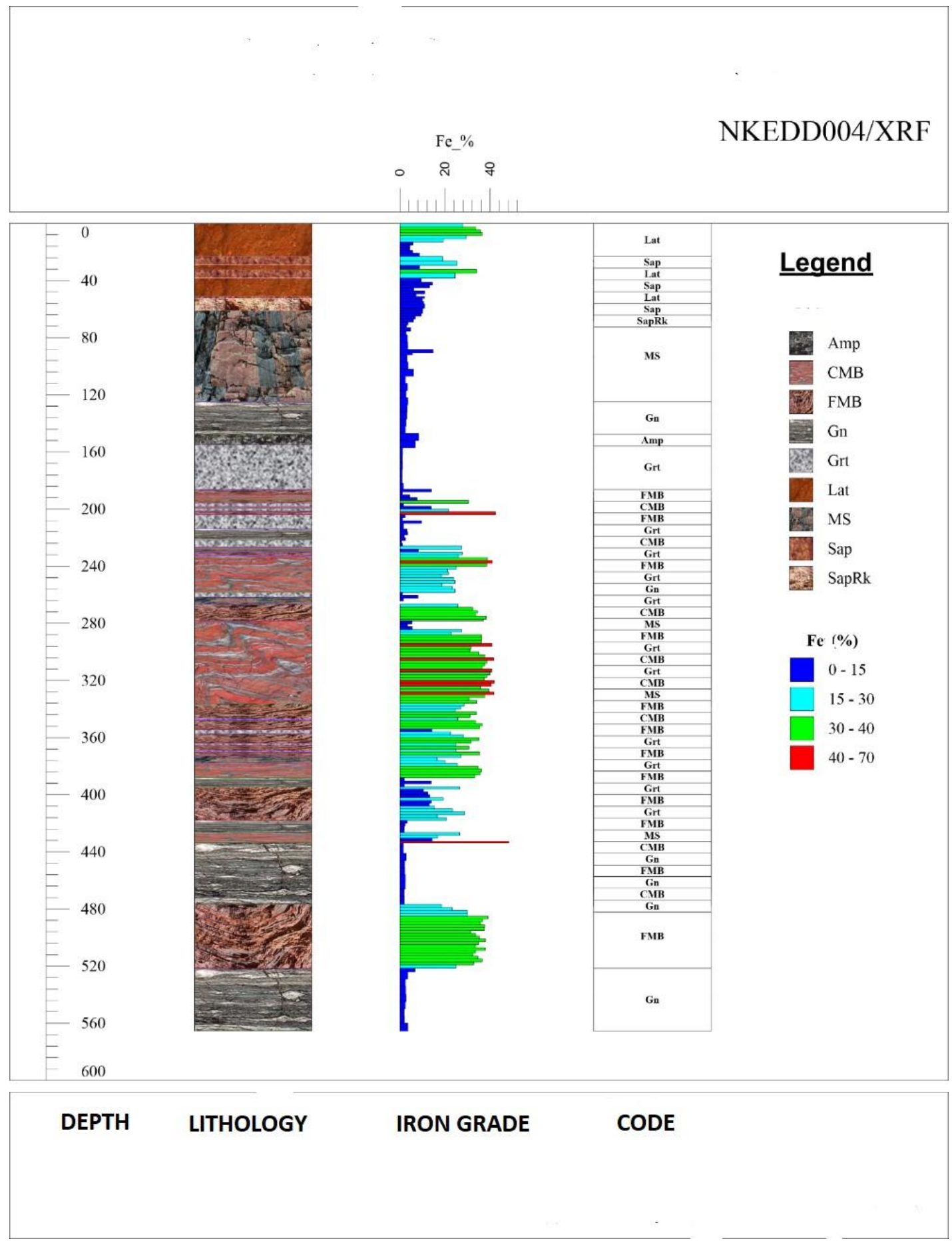




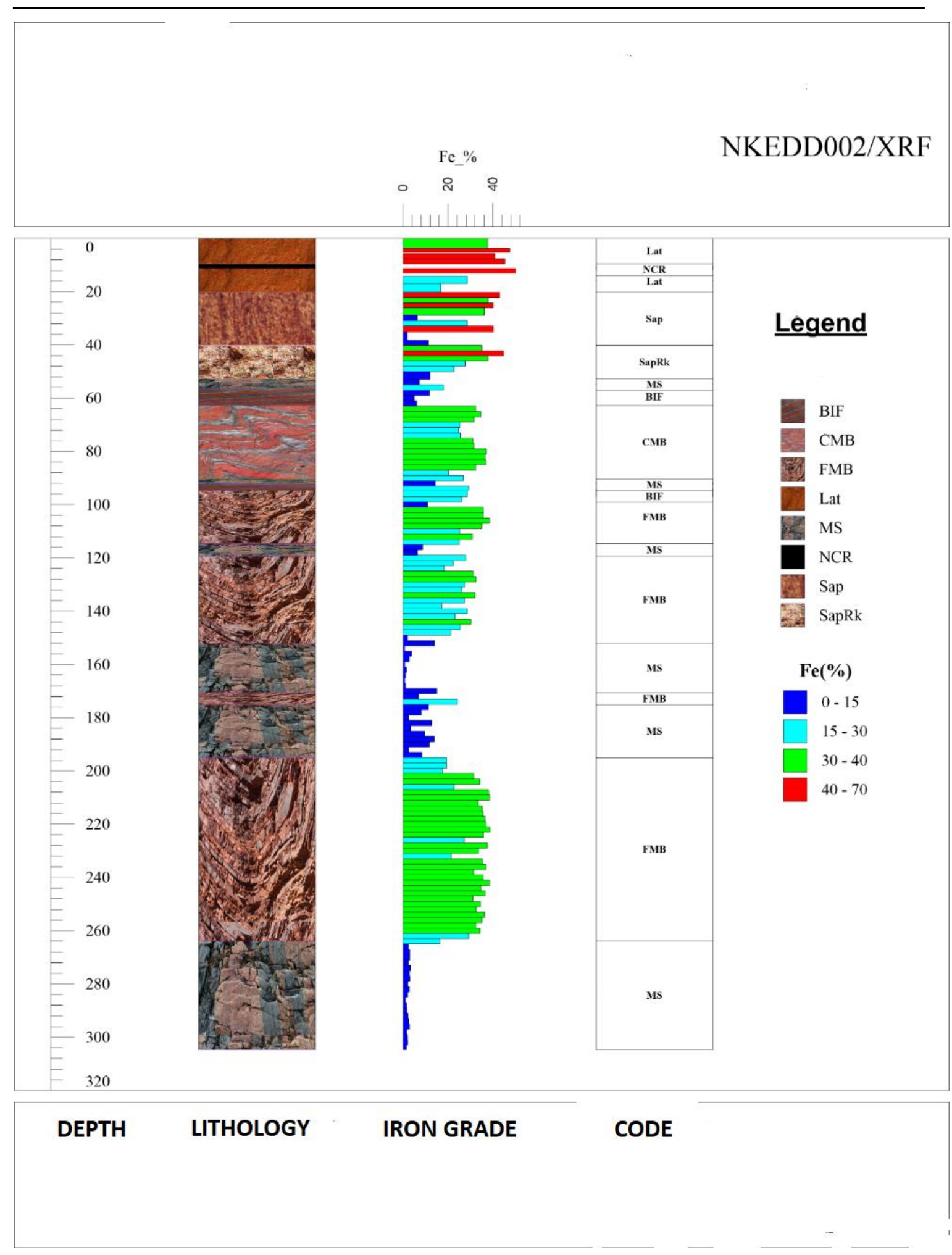


Appendix B MATLAB code for domaining

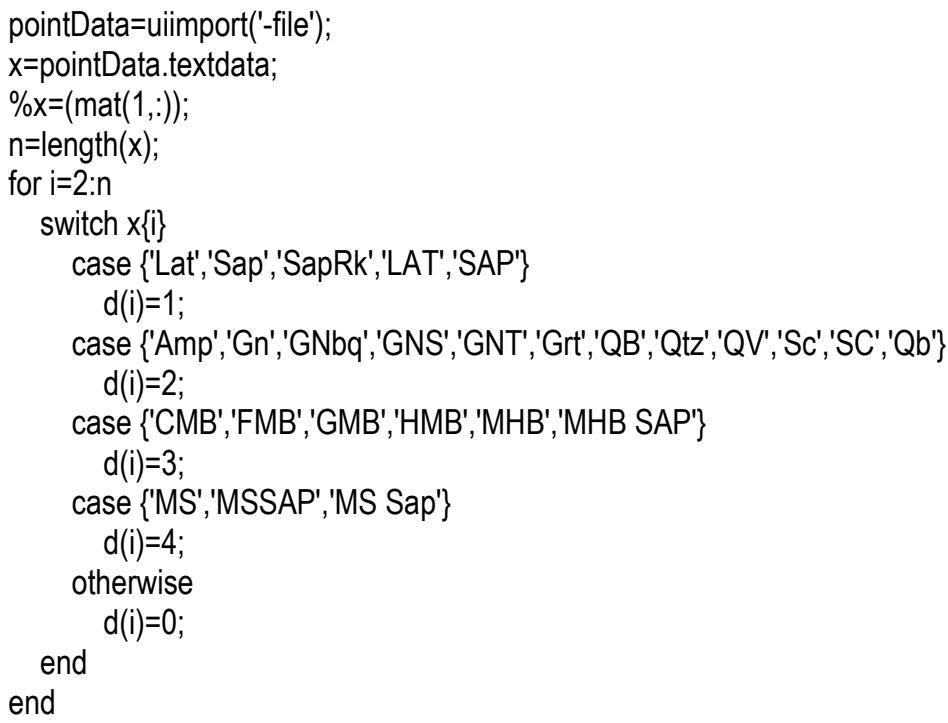




\title{
UTICAJ PODATAKA GEOLOŠKIH DOMENA NA MODELIRANJE I PROCENU RESURSA LEŽIŠTA GVOŽĐA U NKOUT (JUŽNI KAMERUN)
}

\author{
A.W. Boroh ${ }^{1 \#, ~ K . Y . ~ S o r e-G a m o ', ~ M . ~ A y i w o u o ~ N g o u n o u n o ², ~}$ \\ I.B. Gbambie Mbowou', I. Ngounouno ${ }^{1}$ \\ 1 University of Ngaoundere, School of Geology and Mining Engineering, Meiganga, Cameroon \\ 2Ministry of Mines and Technological Industries, Yaoundé, Cameroun
}

Primljen: 16. februar 2021.; Prihvaćen: 29. jul 2021.

\begin{abstract}
Izvod
Ovaj rad se bavi time da li se procena mineralnih resursa može poboljšati uz korišćenje geoloških informacija. Korišćeni geohemijski podaci su sakupljeni sa 116 bušotina u Istočnom Nkout ležištu gvožđa u južnom Kamerunu. Ovi geohemijski podaci su modelovani uz pomoć Surpac i Isatis softvera da bi se prikazala 3D geohemijska distribucija gvožđa u ležištu. Urađene su statističke a zatim i variogramske analize da bi se proučila prostorna distribucija gvožđa. Domeni za procenu definisani su na osnovu rezultata geoloških i geohemijskih analiza. Određena su četiri domena. Ovi domeni su uglavnom saprolit; siromašan domen ili sveže stene kao što su amfiboliti, graniti i gnajsovi,bogat domen ili oksidirane stene (BIF) i domen metasedimenata. Da bi se izvršila proena resursa urađen je blok-model ležišta. Sadržaj u svakom bloko procenjen je upotrebom običnog krigovanja $i$ kompozita iz svakog domena. U ovom radu se takođe porede dve vrste procene -procena domena i globalna procena. Verodostojnost dobijenog modela je potvrđena uz pomoć unakrsne validacije. Procena domena je preciznija od globalne procene, tačnije, u vezi analize grešaka, dok geohemijsko modelovanje daje najbolje rezultate ako uzmemo u obzir oblake tačaka predviđenih i procenjenih vrednosti.
\end{abstract}

Ključne reči: Efekat informacija; Efekat podrške; Geološki domen; Geohemijsko modelovanje. 